\title{
Morpho-molecular characterization of Bipolaris and Exserohilum spp. infecting various agricultural crops
}

\author{
Seema Singh ${ }^{1}$, Sneha Sharma ${ }^{1}$, Aaqib Ali ${ }^{2}$, A Kandan ${ }^{3}$, Pardeep Kumar ${ }^{2}$ and Jameel Akhtar* \\ ${ }^{1}$ Shri Ram College of Ch. Charan Singh University, Muzaffarnagar-251001, Uttar Pradesh, India \\ ${ }^{2}$ Division of Plant Quarantine, ICAR-National Bureau of Plant Genetic Resources, New Delhi 110012, India \\ ${ }^{3}$ Division of Germplasm Conservation and Utilization, ICAR-National Bureau of Agricultural Insect Resources, \\ Bengaluru-560 024, Karnataka, India
}

Corresponding author e-mail: jameelnbpgr@gmail.com

(Received: 18/12/2020; Revised: 29/04/2021; Accepted: 11/06/2021)

\begin{abstract}
The study was undertaken with major objective to differentiate fungal isolates belonging to various species of Bipolaris and Exserohilum infecting various agricultural crops. After routine isolation and purification of more than 35 attempts, 13 isolates were morphologically characterized into 8 species namely, Bipolaris cynodontis (IQBC-1 and DQBC-2), B. holmii (IQBH-1), B. micropus (IQBM-1), B. oryzae (DQBO-1, DQBO-2), B. sorghicola (DQBS-1, DQBS-2), B. tetramera (DQBT-1, DQBT-2), Exserohilum longirostrata (IQEL-1) and E. rostratum (DQER-1 and DQER-2). Molecular characterization of all the isolates using RAPD, ISSR and URP markers also revealed genetic variation. Out of 24 RAPD primers, only 9 (OPA-2, OPA-4, OPA-9, OPB-4, OPB-8, OPC-1, OPC-2, OPC-5 and OPE-5) could amplify the DNA sequence showing good polymorphism. Out of 20 ISSR primers, only 6 (ISSR 1, ISSR 13, ISSR 15, ISSR 17, ISSR 19 and ISSR 20) could show good polymorphism. Out of 13 URPs, only 5 (URP 4R, URP 6R, URP 9F, URP 13R and URP 38F) could amplify with a greater number of bands. In all the three makers, similarity matrix value using Jaccard's coefficient ranged from 0.149 to 0.548 revealing genetic co-relation among isolates. Combined clustering of RAPD, ISSR and URP data showed relatively low genetic similarity coefficient ranging from 14.92 to 54.76 among isolates which revealed stronger co-relation among isolates. Cluster analysis based on UPGMA provided a clear resolution of relationship among all the 13 isolates belong to 6 Bipolaris and 2 Exserohilum species and confirmed the morphological characterization of the same. Further, molecular markers especially, RAPD, ISSR and URP have revolutionized the genetic analysis of plant pathogens including fungi and their application can greatly help in characterizing related genera and delineation of inter and intra-species complex of fungi.
\end{abstract}

Keywords: Bipolaris, molecular characterization, agricultural crops.

\section{INTRODUCTION}

The genus Bipolaris (syn.: Helminthosporium Link) is a member of dematiaceous hyphomycetes with more than 100 species. These are anamorphs of the ascomycetous genus Cochliobolus (family - Pleosporaceae; Order Pleosporales). The members belonging to the genus Bipolaris are known as graminicolous species which are pathogenic to Oryzoideae, Arundinoideae, Festucoideae, Eragrostoideae, and Panicoideae in the family of Gramineae (Weikert-Oliveira et al., 2002). The species of the genus are facultative parasites and cause a number of leaf spots, blights and a variety of symptoms depending on the kinds of diseases on various agricultural crops. There are several species of Bipolaris which caused severe economic losses to crops all over the world (Ueyama et al., 1975). For example, maydis leaf blight/ southern corn blight caused by B. maydis (Nishikado and Miyake) Shoemaker in the USA, brown spot of rice caused B. oryzae damaged more than $90 \%$ yields in South Asia, leaf blight of wheat caused by $B$. sorokiniana, Victoria blight of oat caused by $B$. victoriae, target leaf spot of sorghum caused by $B$. sorghicola, etc. Furthermore, several isolates of the fungi showed pathogenicity to grassy weeds, for example, Exserohilum monoceras to barnyard grass (Echinochloa spp.), B. setariae to goose grass (Eleusine indica), E. rostratum and Exserohilum sp. to red sprangle top (Leptochloa chinensis). There are indications that during the World War II, Bipolaris oryzae was also used as bioweapon by the USA in Japan (https://species.nbnatlas.org/species/BMSSYS0000042 972).

Species belonging to the genera, Bipolaris and Exserohilum have been characterized based on morphological descriptions including rapidly growing dark colonies, geniculate conidiophores with sympodial 
conidiogenesis and macro conidial measurement with varying number of transverse distosepta, usually without a protuberant hilum and with bipolar germination. But these are not significantly sufficient enough to accurately characterize various isolates into species. Now a days, molecular techniques are extensively used to resolve the issue of species level characterization in fungi (Caligiorne et al., 1999; Aggarwal et al., 2008; Kumar et al., 2018). Various works have characterized species of Bipolaris and Exserohilum from different crops based on morpho-molecular characterization (Bakonyi et al., 1995; Mehta, 2001; Weikert-Oliveira et al., 2002; Motlagh \& Kaviani, 2008; Motlagh \& Anvari, 2010; Kandan et al., 2014; Kandan et al., 2016). Therefore, keeping in view of the importance of the genus Bipolaris infecting various agricultural crops, the study was carried out to inter-species level differentiation in the genera Bipolaris and Exserohilum using morphomolecular characterization.

\section{MATERIALS AND METHODS}

The experiment was conducted in the Division of Plant Quarantine, ICAR-NBPGR, New Delhi. During seed health testing using blotter test of incubation method (Mathur \& Kongsdal, 2003) for quarantine and conservation, fungal growth on seeds of various crops received from various sources (Table 1) were observed under stereo-binocular microscope (Nikon - SMZ 1500) at different levels of magnification i.e., $0.75 \mathrm{X}$ to $11.25 \mathrm{X}$ on $8^{\text {th }}$ day of incubation. The associated fungi were identified on the basis of colony characters, fruiting bodies and spores under stereo-zoom microscope and slides using mounting media (lactophenol/ cotton blue) were also prepared and examined under compound microscope (Nikon - Eclipse 80i). Purification after routine isolation of fungi (13 isolates) was done using modified isolation technique (Akhtar et al., 2014) on PDA medium for their molecular characterization using using random amplified polymorphic DNA (RAPD), Inter simple sequence repeats (ISSR) and universal rice primer (URP). Some selected primers designed for RAPD (OPA-2, OPA-4, OPA-9, OPB-4, OPB-8, OPC1, OPC-2, OPC-5 and OPE-5), ISSR (ISSR 1, ISSR 13, ISSR 15, ISSR 17, ISSR 19 and ISSR 20) and URP (URP 4R, URP 6R, URP 9F, URP 13R and URP 38F) were used to amplify DNA of Bipolaris and Exserohilum spp. For molecular characterization, the genomic DNA was extracted from freshly harvested mycelial mat of all the 13 isolates using CTAB method. The quality and concentration of the extracted DNA was then assessed by spectrophotometer and the concentration of DNA

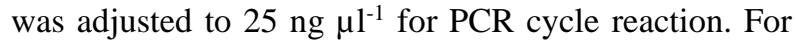
the PCR cycle, in $12.5 \mu \mathrm{l}$ PCR master mix, 1x PCR buffer $1 \mu 1,50 \mathrm{ng}$ Template DNA, $2.5 \mathrm{mM}$ dNTPs, $1 \mathrm{U}$ Taq DNA polymerase and $0.2 \mathrm{mM}$ each of RAPD, ISSR and URP primers were added.

PCR was performed in thermocycler (Genepro, Bioer) following specific conditions for RAPD primers such as initial activation at $94^{\circ} \mathrm{C}$ for $4 \mathrm{~min}$. followed by denaturation at $94^{\circ} \mathrm{C}$ for $5 \mathrm{sec}$., annealing at $32^{\circ} \mathrm{C}$ for 30 sec. (OPB-4, OPC-1, OPE-5) and $34^{\circ} \mathrm{C}$ for $30 \mathrm{sec}$. (OPA-2, 4, 9, OPB-8, OPC-2, 5) and extension at $72^{\circ} \mathrm{C}$ for $15 \mathrm{sec}$. and final extension cycle at $72^{\circ} \mathrm{C}$ for $10 \mathrm{~min}$.), ISSR primers (initial activation at $94^{\circ} \mathrm{C}$ for $4 \mathrm{~min}$. followed by denaturation at $94^{\circ} \mathrm{C}$ for $30 \mathrm{sec}$., annealing at $39^{\circ} \mathrm{C}$ for $30 \mathrm{sec}$. (ISSR-17), $40^{\circ} \mathrm{C}$ for $30 \mathrm{sec}$. (ISSR$15,19), 43^{\circ} \mathrm{C}$ for $30 \mathrm{sec}$. (ISSR-1) and $46^{\circ} \mathrm{C}$ for $30 \mathrm{sec}$. (ISSR-13, 20) and extension at $72^{\circ} \mathrm{C}$ for $2 \mathrm{~min}$. and final extension cycle at $72^{\circ} \mathrm{C}$ for $10 \mathrm{~min}$. and for URP primers, initial activation at $94^{\circ} \mathrm{C}$ for $4 \mathrm{~min}$. followed by denaturation at $94^{\circ} \mathrm{C}$ for $30 \mathrm{sec}$., annealing at $49^{\circ} \mathrm{C}$ for $30 \mathrm{sec}$. (URP 9F, 13R, 38F), $50^{\circ} \mathrm{C}$ for $30 \mathrm{sec}$.(URP 4R), $54^{\circ} \mathrm{C}$ for $30 \mathrm{sec}$. (URP 6R), extension at $72^{\circ} \mathrm{C}$ for $2 \mathrm{~min}$. and final extension at $72^{\circ} \mathrm{C}$ for $10 \mathrm{~min}$. The PCR products were run in an agarose gel $(1.2 \%) 1 \mathrm{~h} 15 \mathrm{~min}$ at a current of 120 Volt with ethidium bromide staining.

After electrophoresis, gel was observed under UV transilluminator. RAPD, ISSR and URP data were analysed using the statistical package of the NTSYS-pc (Rohlf, 1988). The relationship among 13 isolates isolates belonging to Bipolaris and Exserohilum was estimated by means of scorable DNA bands amplified from RAPD, ISSR and URP markers. Each band was considered as character and was scored as either 1 for present or o for absent. Similarity between isolates was assessed by calculating the simple association coefficient and cluster analysis using the unweighted pair group method with arithmetical averages (UPGMA).

\section{RESULTS AND DISCUSSION}

The collection of the isolates of Bipolaris and Exserohilum were made from seeds of different crops and indigenous as well as exotic sources. After their purification based on their growth character on PDA, finally thirteen isolates were selected to study the extent and magnitude of differences and variability for their characterization. Different aspects studied are described as follows. The observation pertaining to morphological characters such as colony growth, shape, colour, texture, zonation, etc., conidial shape, size, septation, conidiophore, etc. (Table 1) characterized all the isolates into 6 species belonging of the genus Bipolaris and 2 species of the Exserohilum. The isolates, DQBC-2 and IQBC-1 similar in their morphology were characterized as Bipolaris cynodontis (Marignoni) Shoemaker. Two other isolates, DQBO-1 and DQBO-2 showing similarity in their growth characteristics were characterized as Bipolaris oryzae (Breda de Haan) Shoemaker. Two isolates, DQBS-1 and DQBS-2 isolated from sorghum of Madhya Pradesh and Karnataka showed similar characteristics but distinctly different from other isolates were identified as Bipolaris sorghicola (Lefebvre \& Sherwin) Alcorn. Based on morphological characters, isolate IQBH-1 isolated from chilli was identified as Bipolaris holmii (Luttr.) Subram. \& B.L. Jain. Another two isolates recovered from snake gourd (DQBT-1) of 
Table 1. Morphological characterization using growth features and other details of 13 isolates of Bipolaris and Exserohilum spp.

\begin{tabular}{|c|c|c|c|c|c|c|c|}
\hline Isolate & Host & Source & Shape/ type & Septation & $\begin{array}{l}\text { Dimension } \\
(\mu \mathrm{m})\end{array}$ & Attachment & Fungus \\
\hline DQBS-1 & Sorghum & $\begin{array}{l}\text { Madhya } \\
\text { Pradesh, } \\
\text { India } \\
\text { Karnataka, } \\
\text { India }\end{array}$ & \multicolumn{2}{|l|}{$\begin{array}{l}\text { Conidia pale to brown, } \\
\text { ellipsoid, straight to } \\
\text { slightly curved, } \\
\text { gradually tapering } \\
\text { towards the rounded } \\
\text { ends }\end{array}$} & $50-85 \times 12-15$ & $\begin{array}{l}\text { Conidia in chains } \\
\text { and looks deceptive } \\
\text { and attached to } \\
\text { secondary } \\
\text { conidiophores }\end{array}$ & B. sorghicola \\
\hline IQBH-1 & Chilli & USA & $\begin{array}{l}\text { Conidia smooth walled, } \\
\text { broadly rostrate, } \\
\text { ellipsoidal, with end } \\
\text { cells often rather pale, } \\
\text { intermediate cells mid } \\
\text { dark golden brown, } \\
\text { hilum protuberant }\end{array}$ & $\begin{array}{l}6-11 \\
\text { pseudoseptate }\end{array}$ & $75-100 \times 20-30$ & $\begin{array}{l}\text { Conidiophores } \\
\text { solitary or in small } \\
\text { groups, straight or } \\
\text { flexuous, pale to } \\
\text { dark brown, up to } \\
280 \mu \mathrm{m} \text { long, 6-10 } \\
\mu \mathrm{m} \text { thick, sometimes } \\
\text { with a basal swelling } \\
\text { up to } 18 \mu \mathrm{m}\end{array}$ & B. holmii \\
\hline DQBT-1 & $\begin{array}{l}\text { Snake } \\
\text { gourd }\end{array}$ & $\begin{array}{l}\text { Kerala, } \\
\text { India }\end{array}$ & $\begin{array}{l}\text { Conidia smooth walled, } \\
\text { majority dark brown, } \\
\text { lighter towards terminal } \\
\text { cells, cylindric, straight } \\
\text { with rounded ends }\end{array}$ & 3 distoseptate & $22-26 \times 8-15$ & $\begin{array}{l}\text { Conidiophores short } \\
\text { to medium, single or } \\
\text { in groups of } 2-3 \text {, } \\
\text { bearing } \\
\text { acropleurogeneously }\end{array}$ & B. tetramera \\
\hline DQER-1 & Sorghum & $\begin{array}{l}\text { Uttar } \\
\text { Pradesh, } \\
\text { India } \\
\text { Uttar } \\
\text { Pradesh, } \\
\text { India }\end{array}$ & $\begin{array}{l}\text { Conidia with huge } \\
\text { variation in shape and } \\
\text { size, mostly brown to } \\
\text { shiny black, ellipsoid to } \\
\text { rostrate and } \\
\text { longirostrate }\end{array}$ & $\begin{array}{l}3-12 \\
\text { distoseptate }\end{array}$ & $15-460 \times 10-25$ & $\begin{array}{l}\text { Conidia attached } \\
\text { acropleurogeneously } \\
\text { on short to medium } \\
\text { single conidiophores } \\
\text { or in groups of } 2-3\end{array}$ & $\begin{array}{l}\text { Exserohilum } \\
\text { rostrata }\end{array}$ \\
\hline IQEL-1 & Rice & USA & $\begin{array}{l}\text { Conidia with huge } \\
\text { variation in shape and } \\
\text { size, mostly olivaceous } \\
\text { brown and } \\
\text { longirostrate, apical } \\
\text { cell in some conidia } \\
\text { bulbous }\end{array}$ & $\begin{array}{l}12-26 \\
\text { distoseptate }\end{array}$ & $\begin{array}{l}\text { Up to } 460 \times 10- \\
25\end{array}$ & $\begin{array}{l}\text { Conidia attached } \\
\text { acropleurogeneously } \\
\text { on short to medium } \\
\text { single conidiophores } \\
\text { or in groups of } 2-3\end{array}$ & $\begin{array}{l}\text { E. } \\
\text { longirostratum }\end{array}$ \\
\hline
\end{tabular}


Kerala and chilli (DQBT-2) of Meghalaya with smooth walled, mostly dark brown conidia having lighter colour towards terminal cells, cylindric and straight with rounded ends were identified as Bipolaris tetramera (Mikinney) Subram. \& Jain. An isolate recovered from tomato of Taiwan (IQBM-1) with conidial characteristics such as 4-7 septa, light brown, small, ellipsoid, broader in the middle, tapering towards ends, apex rounded, small protruding hilum measuring 37.4$52.7 \times 11.9-13.6 \mu \mathrm{m}$ in dimension was characterized as Bipolaris micropus (Drechsler) Shoemaker. The isolates, DQER-1 and DQER-2 from sorghum of Uttar Pradesh were characterized by very long, slender, acropleurogenous, olivaceous brown, very long 6-26 septate conidia on short to medium conidiophores, hilum protuberant, measuring $63-462 \times 12-25 \mu \mathrm{m}$ as Exserohilum rostratum (Drechsler) K.J. Leonard \& Sugg. Whereas, one isolate, IQEL-1 recovered from rice of USA showing huge variation in conidial shape and size, mostly longirostrate and olivaceous brown in colour was characterized as Exserohilum longirostrata (Subramanian) Sivanesan. These results are partially similar to those findings published by various workers (Mathur \& Kongsdal, 2003; Fajolu, 2012; Fatima et al., 2015; Kumar et al., 2016; Valarmathi \& Ladhalakshmi; 2018; Karami et al., 2020).

All the 13 isolates belonging to Bipolaris and Exserohilum spp. were further characterized using RAPD, ISSR and URP markers. In case of RAPD analysis, 24 RAPD primers were used for characterization of Bipolaris and Exserohilum isolates, of which only 9 primers revealed good polymorphic and monomorphic banding patterns giving average amplicon size between $3.0-0.20 \mathrm{~kb}$. Similarity matrix value using Jaccard's coefficient ranged from 0 to 1 . There was total 781 bands revealed from 13 RAPD primers in which primer OPA-4 showed a greater number of bands at annealing temperature $32^{\circ} \mathrm{C}$. The number of polymorphic band $(\mathrm{PM})=172$, expected heterozygosity $(\mathrm{Hn})=2.67$, average heterozygosity $(\beta)=9$, effective multiplex ratio $(\mathrm{EMR})=172$, marker index $(\mathrm{MI})=50.55$ (Table 2). The analysis showed genetic similarity among all the 13 isolates obtained from different hosts and geographical regions barring few exceptions. Genetic similarity coefficient was relatively low among all the isolates which ranged from 0.111 to 0.535 (Fig. 1a). Based on UPGMA analysis all the isolates were classified into two major clusters in which cluster 1 contain 11 isolates which is further divided into two minor clusters $\mathrm{A}$ and $\mathrm{B}$. Cluster a consist of 7 isolates (DQSR-1, IQEL-1, DQER-2, DQBS-1, IQBH-1, IQBM1, DQBS-2) from Uttar Pradesh, USA, Madhya Pradesh, Taiwan and Karnataka which shows upto $48 \%$ similarity between isolates DQER-1 and IQEL-1 from Uttar Pradesh, USA and their boot straps value is 60 . Cluster B consists of 4 isolates (DQBO-1, DQBO-2, DQBT-1 and DQBT-2) from Tamil Nadu, Kerala and Meghalaya which shows $55 \%$ similarity in their isolates, DQBT-1 and DQBT-2 with their boot up value 99. Cluster 2 has
2 isolates with $50 \%$ similarity in isolates IQBC-1 and DQBC-2 from USA and Telangana with their boot straps value 99 (Table 2).

On the other hand, ISSR primers also showed good polymorphism with 6 primers out of 20 primers screened with more polymorphic bands. There was total 558 bands revealed by 6 ISSR primers showing average band size between $3.0-0.10 \mathrm{~kb}$. The primer, ISSR 13 showed a greater number of bands at annealing temperature $46^{\circ} \mathrm{C}$. The number of alleles is $109, \mathrm{PM}=109, \mathrm{Hn}=1.91$, $\beta=6, E M R=109$ and $M I=34.24$. Similarity matrix value using Jaccard's coefficient ranged from 0.106 to 0.677 by which we find the genetic co-relation among all the isolates (Table 2; Fig. 1b, 2b). The analysis showed genetic similarity among isolates obtained from different hosts and geographical regions barring few exceptions. Genetic similarity coefficient was relatively low among all the isolates which ranged from 0.106 to 0.677 . Based on UPGMA analysis all the isolates were classified into 2 major cluster in which cluster 1 contains 9 isolates DQER-1, DQBC-2, IQBH-1, IQBC-1, DQER-2, IQEL1, DQBS-1, DQBS-2 and IQBM-1 from Uttar Pradesh, Telangana, USA, Madhya Pradesh, Karnataka and Taiwan which showed upto $50 \%$ similarity between isolates DQER-2 and IQEL-1 from Uttar Pradesh and USA with their boot straps value 64. Cluster 2 have 4 isolates DQBO-1, DQBO-2, DQBT-1 and DQBT-2 from Tamil Nadu, Kerala and Meghalaya which showed upto $70 \%$ similarity between isolates DQBO-1 and DQBO-2 from Tamil Nadu with their boot straps value 99. Isolate IQBM-1 is not included in any cluster, this is not showing similarity with any isolates.

Whereas, URPs also showed good polymorphism with 5 primers out of 13 primers screened with more bands. There was total 450 bands revealed by 5 URPs showing average band size between $3.0-0.10 \mathrm{~kb}$. The primer, URP 6R showed a greater number of bands at annealing temperature $54^{\circ} \mathrm{C}$. The number of $\mathrm{PM}=98, \mathrm{Hn}=1.48$, $\beta=5, E M R=98$ and $M I=29.04$. Similarity matrix value using Jaccard's coefficient ranged from 0.094 to 0.640 by which we find the genetic co-relation among all the isolates. Genetic similarity coefficient was relatively low among all the isolates which ranged from 0.094 to 0.640 (Table 2; Fig. 1c, 2c). Based on UPGMA analysis all the isolates were classified into 2 major cluster in which cluster 1 contain 10 isolates which is further divided into two clusters A and B. Cluster A consist of 7 isolates DQER-1, DQER-2, IQEL-1, IQBH-1, IQBM-1, IQBC-1 and DQBC-2 from Uttar Pradesh, USA, Taiwan and Telangana which showed upto 55\% similarity between isolates DQER-2 and IQEL-1 from Uttar Pradesh and USA and their boot straps value is 91 . Cluster $b$ consist of 3 isolates DQBO-1, DQBO-2 and DQBS-1 from Tamil Nadu and Madhya Pradesh which showed upto $52 \%$ similarity between isolates DQBO-1 and DQBO-2 from Tamil Nadu and their boot up value is 94 . Cluster 2 have 3 isolates DQBT-1, DQBT-2 and DQBS-2 from Kerala, Meghalaya and Karnataka which showed upto 65\% similarity between isolates DQBT-1 and DQBT-2 
from Kerala and Meghalaya and their boot up value is 99. Isolate DQER-1 and DQBS-2 were not clubbed in any cluster, hence, not showing similarity with any isolate.

In combined analysis of RAPD, ISSR and URP data, stronger co-relation among isolates was observed which could realize the similarity coefficient relation among the isolates in combined form (Fig. 1d). The analysis showed genetic similarity among different isolates obtained from different hosts and geographical regions in a combined form using three types of primers. Genetic similarity coefficient was relatively low among all the isolates which ranged from 14.92 to 54.76. Based on UPGMA analysis all the isolates were classified into 2 major clusters. $1^{\text {st }}$ cluster consist of 9 isolates DQSR-1, DQSR-2, IQBL-1, IQBH-1, IQBC-1, DQBC-2, DQBS1, DQBS-2 and IQBM-1 from Uttar Pradesh, USA, Telangana, Madhya Pradesh, Karnataka and Taiwan which showed upto $50 \%$ similarity between isolates IQBC-1 and DQBC-2 from USA and Telangana and their boot straps value is 100 . Cluster 2 has 4 isolates DQBO-1, DQBO-2, DQBT-1 and DQBT-2 from Tamil Nadu, Kerala and Meghalaya which showed upto $55 \%$ similarity between isolates DQBT-1 and DQBT-2 from Kerala and Meghalaya and their boot straps value is 100 .

Table 2. RAPD, ISSR and URP primers showing various marker utility parameters against 13 isolates of Bipolaris and Exserohilum spp.

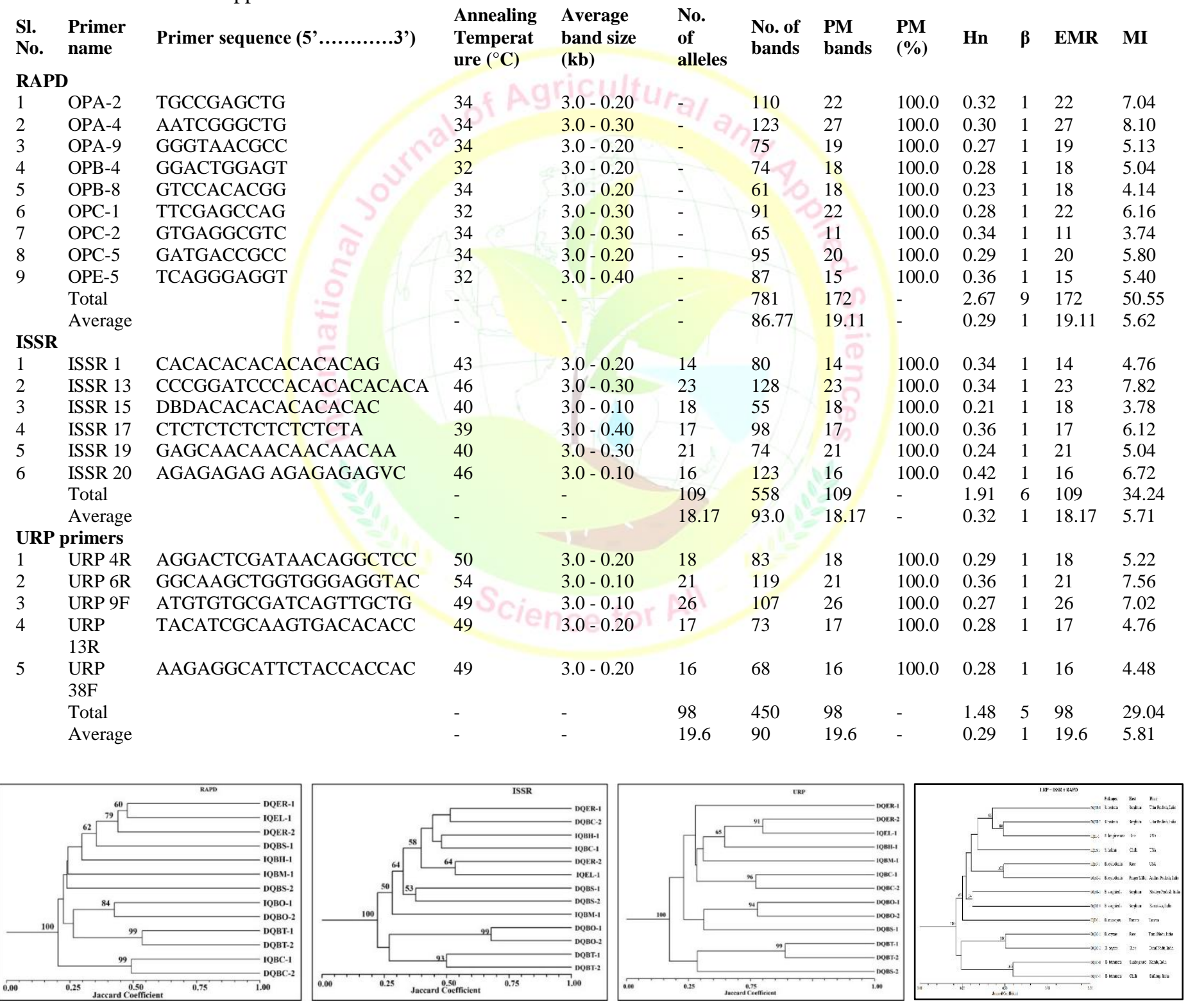

Fig. 1. Dendrogram obtained from 13 isolates of Bipolaris and Exserohilum species showing UPGMA based similarity coefficient with a) RAPD, b) ISSR, c) URP d) combined primers. 
Table 3. Jaccard's coefficient of genetic similarity derived from data generated by RAPD, ISSR, URP and combined primers analysis of 13 isolates of Bipolaris and Exserohilum spp.

\begin{tabular}{|c|c|c|c|c|c|c|c|c|c|c|c|c|c|}
\hline Isolate & $\begin{array}{l}\mathrm{DQE} \\
\mathrm{R}-1\end{array}$ & $\begin{array}{l}\mathrm{DQE} \\
\mathrm{R}-2\end{array}$ & $\begin{array}{l}\text { IQB } \\
\text { M-1 }\end{array}$ & $\begin{array}{l}\mathrm{IQE} \\
\mathrm{L}-1\end{array}$ & $\begin{array}{l}\text { IQB } \\
\mathrm{H}-1 \\
\end{array}$ & $\begin{array}{l}\text { IQB } \\
\text { C-1 }\end{array}$ & $\begin{array}{l}\text { DQB } \\
\mathrm{C}-2\end{array}$ & $\begin{array}{l}\text { DQB } \\
\mathrm{O}-1\end{array}$ & $\begin{array}{l}\text { DQB } \\
\text { O-2 }\end{array}$ & $\begin{array}{l}\text { DQB } \\
\mathrm{T}-1\end{array}$ & $\begin{array}{l}\mathrm{DQB} \\
\mathrm{T}-2\end{array}$ & $\begin{array}{l}\text { DQB } \\
\text { S-1 }\end{array}$ & $\begin{array}{l}\text { DQB } \\
\text { S-2 }\end{array}$ \\
\hline \multicolumn{14}{|l|}{ RAPD } \\
\hline DQER-1 & 1 & & & & & & & & & & & & \\
\hline DQER-2 & 45.71 & 1 & & & & & & & & & & & \\
\hline IQBM-1 & 23.85 & 28.97 & 1 & & & & & & & & & & \\
\hline IQEL-1 & 47.57 & 42.2 & 28.03 & 1 & & & & & & & & & \\
\hline IQBH-1 & 28.57 & 33.63 & 21.69 & 30.35 & 1 & & & & & & & & \\
\hline IQBC-1 & 18.44 & 19.04 & 18.88 & 21.56 & 27.47 & 1 & & & & & & & \\
\hline DQBC-2 & 19.6 & 17.92 & 21.59 & 21.56 & 27.47 & 49.2 & 1 & & & & & & \\
\hline DQBO-1 & 28.15 & 32.35 & 23.15 & 25.23 & 21.15 & 15.55 & 22.35 & 1 & & & & & \\
\hline DQBO-2 & 15.78 & 20.53 & 23.15 & 18.58 & 18.86 & 19.54 & 22.35 & 42.5 & 1 & & & & \\
\hline DQBT-1 & 15.31 & 25.96 & 17.7 & 19.26 & 24.49 & 14.94 & 11.11 & 25 & 23.59 & 1 & & & \\
\hline DQBT-2 & 22.43 & 27.61 & 13.72 & 27.88 & 26.26 & 24.09 & 19.76 & 26.96 & 29.88 & 53.52 & 1 & & \\
\hline DQBS-1 & 33.67 & 39.58 & 18.36 & 33 & 26.26 & 21.17 & 22.61 & 36.14 & 22.82 & 15.95 & 25.84 & 1 & \\
\hline DQBS-2 & 21.35 & 23.07 & 23.59 & 20.95 & 27.95 & 21.25 & 19.75 & 20.22 & 22.98 & 15.73 & 20.45 & 26.19 & 1 \\
\hline \multicolumn{14}{|l|}{ ISSR } \\
\hline DQER-1 & 1 & & & & & & & & & & & & \\
\hline DQER-2 & 52.11 & 1 & & & & & & & & & & & \\
\hline IQBM-1 & 29.41 & 31.34 & 1 & & 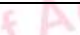 & 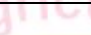 & 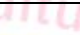 & $=1$ & & & & & \\
\hline IQEL-1 & 40 & 53.42 & 26.02 & 1 & 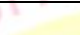 & & & 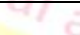 & & & & & \\
\hline IQBH-1 & 45.83 & 36.36 & 26.86 & 36.25 & 1 & & & & $7 \rho$ & & & & \\
\hline IQBC-1 & 38.75 & 38.75 & 30 & 38.55 & 47.94 & 1 & & & & & & & \\
\hline$\overline{\mathrm{DQBC}-2}$ & 51.38 & 39.74 & 30.88 & 36.14 & 45.2 & 47.36 & 1 & & & & & & \\
\hline DQBO-1 & 25 & 19.4 & 22.44 & 23.52 & 30.5 & 33.87 & 24.61 & 1 & & 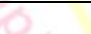 & & & \\
\hline DQBO-2 & 25 & 21.21 & 17.64 & 25.37 & 28.33 & 33.87 & 24.61 & 67.74 & 1 & 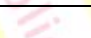 & & & \\
\hline DQBT-1 & 18.46 & 18.46 & 26.66 & 15.71 & 19.35 & 29.03 & 18.18 & 32.43 & 28.94 & 1 & & & \\
\hline DQBT-2 & 13.43 & 15.15 & 27.27 & 14.28 & 10.6 & 25.39 & 14.92 & 17.07 & 29.73 & 50 & 1 & & \\
\hline DQBS-1 & 33.33 & 38.66 & 27.27 & 36.7 & 27.84 & 35.44 & 34.61 & 22.58 & 26.66 & 19.67 & 20 & 1 & \\
\hline DQBS-2 & 32 & 32 & 23.43 & 25.61 & 23.07 & 37.83 & 33.33 & 20.33 & 16.39 & 28.3 & 24.07 & 37.68 & 1 \\
\hline \multicolumn{14}{|l|}{ URP } \\
\hline DQER-1 & 1.00 & 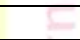 & & & & $t$ & 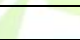 & 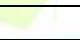 & & 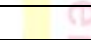 & & & \\
\hline DQER-2 & 37.50 & 1.00 & & & & H & 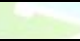 & & & $=$ & & & \\
\hline IQBM-1 & 27.27 & 31.76 & 1.00 & & 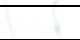 & & 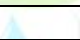 & & & & & & \\
\hline IQEL-1 & 27.41 & 55.07 & 33.76 & 1.00 & & & & & & & & & \\
\hline IQBH-1 & 19.35 & 36.00 & 27.27 & 43.07 & 1.00 & +4 & 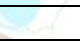 & & & & & & \\
\hline IQBC-1 & 30.18 & 34.72 & 25.67 & 31.34 & 27.69 & 1.00 & 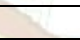 & 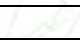 & & 10 & & & \\
\hline DQBC-2 & 25.49 & 31.42 & 23.94 & 23.88 & 27.86 & 52.08 & 1.00 & 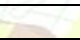 & & 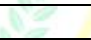 & & & \\
\hline$\overline{\text { DQBO-1 }}$ & 22.00 & 28.98 & 23.18 & 35.59 & 22.95 & 32.07 & 22.64 & 1.00 & & 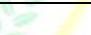 & & & \\
\hline$\overline{\mathrm{DQBO}-2}$ & 20.00 & 24.24 & 20.00 & 23.72 & 17.24 & 28.57 & 26.08 & 52.77 & 1.00 & & & & \\
\hline DQBT-1 & 11.36 & 11.59 & 15.87 & 15.25 & 10.52 & 9.43 & 17.77 & 13.63 & 13.15 & 1.00 & & & \\
\hline DQBT-2 & 13.04 & 14.28 & 15.15 & 16.39 & 15.78 & 15.09 & 21.73 & 20.45 & 24.32 & 64.00 & 1.00 & & \\
\hline DQBS-1 & 10.87 & 19.69 & 15.38 & 20.69 & 25.00 & 25.00 & 22.22 & 30.00 & 32.35 & 17.64 & 22.85 & 1.00 & \\
\hline DQBS-2 & 11.11 & 20.00 & 13.84 & 23.21 & 20.75 & 25.53 & 28.57 & 15.90 & 18.91 & 25.8 & 31.25 & 28.12 & 1.00 \\
\hline \multicolumn{14}{|c|}{ Combine markers analysis } \\
\hline DQSR-1 & 1 & & & & & & & & & & & & \\
\hline DQSR-2 & 45.41 & 1 & & & & & & & & & & & \\
\hline IQBM-1 & 26.33 & 30.50 & 1 & & & & & & & & & & \\
\hline IQBL-1 & 40.00 & 49.00 & 29.18 & 1 & & & & & & & & & \\
\hline IQSH-1 & 31.30 & 35.11 & 24.80 & 35.40 & 1 & & & & & & & & \\
\hline IQBC-1 & 27.96 & 29.57 & 24.35 & 29.76 & 34.06 & 1 & & & & & & & \\
\hline DQBC-2 & 31.11 & 28.34 & 25.11 & 26.98 & 33.33 & 49.19 & 1 & & & & & & \\
\hline DQBO-1 & 25.80 & 27.73 & 23.00 & 27.35 & 24.10 & 25.36 & 23.15 & 1 & & & & & \\
\hline DQBO-2 & 19.28 & 21.72 & 20.85 & 21.75 & 20.98 & 26.26 & 23.98 & 50.34 & 1 & & & & \\
\hline DQBT-1 & 15.45 & 19.74 & 19.11 & 17.22 & 19.35 & 17.82 & 14.92 & 23.66 & 22.42 & 1 & & & \\
\hline DQBT-2 & 17.72 & 20.33 & 16.98 & 20.85 & 18.91 & 22.11 & 18.59 & 22.98 & 28.57 & 54.76 & 1 & & \\
\hline DQBS-1 & 28.82 & 33.75 & 20.08 & 31.22 & 26.52 & 27.35 & 27.05 & 30.27 & 25.80 & 17.46 & 23.37 & 1 & \\
\hline DQBS-2 & 22.87 & 25.00 & 20.42 & 23.04 & 24.55 & 28.35 & 26.76 & 19.27 & 20.00 & 21.38 & 23.56 & 30.81 & 1 \\
\hline
\end{tabular}




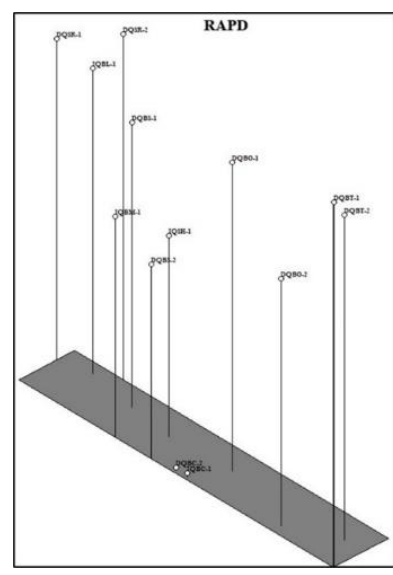

a.

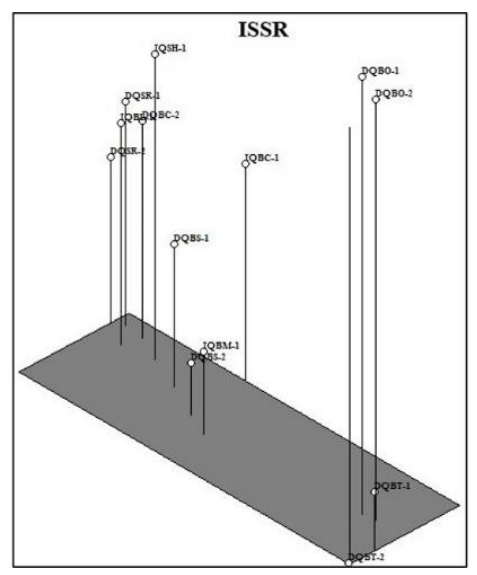

b.

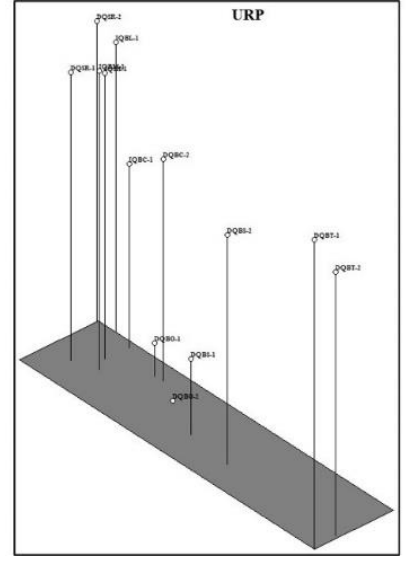

c.

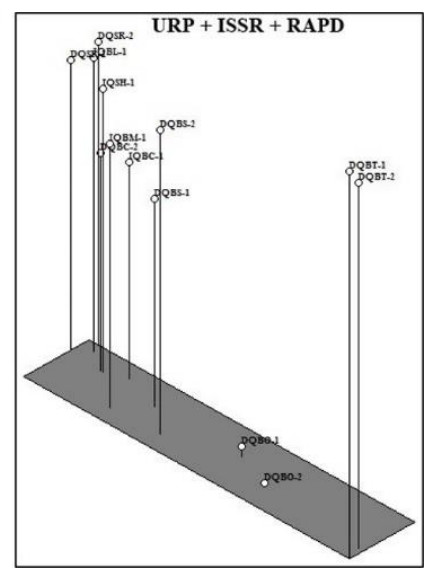

d.

Fig. 2. 3D image analysis of Bipolaris and Exserohilum species using different markers; a) RAPD, b) ISSR, c) URP, and d) combined primer.

After primer screening against different Bipolaris and Exserohilum species using URP, RAPD and ISSR primers combinations we selected some primers which were showing good polymorphic banding pattern. In case of RAPD analysis, out of 24 primers screened, 9 were selected for genetic analysis. Molecular markerbased technologies have revolutionized the genetic analysis of fungus and its application can greatly help in varietal application and genotype individualization. Cluster analysis based on UPGMA provided a clear resolution of relationship among all 11 isolates of Bipolaris and 2 isolates of Exserohilum species. The RAPD primers anneals the specific sequence in the DNA of these 13 isolates they generated a profile (Fig. 1a, 2a) which showed that the isolates DQBT-1, DQBT-2 have highest similarity as they are from Kerala and Meghalaya. We also observed that isolates collected from different place are somewhere showing good similarity this may be due to same climatic conditions. In case of ISSR, out of 20 primers 6 were selected for genetic analysis. Cluster analysis based on UPGMA provided a clear resolution of relationship among all 13 isolates Bipolaris and Exserohilum spp. The ISSR primers annealed the specific sequence in the DNA of these 13 isolates they generated a profile (Fig. 1b, 2b) which showed that the isolates DQBO-1, DQBO-2 have highest similarity as they are from Tamil Nadu. We also observed that isolates collected from different place are somewhere showing good similarity this may be due to similar climatic conditions.

In case of URPs, out of 13 primers, 5 were selected for genetic analysis which could characterized all the 13 isolates of Bipolaris and Exserohilum (Fig. 1c, 2c). Isolate DQER-1 from Uttar Pradesh and DQBS-2 from Karnataka were not showing similarity from other 11 isolates because of great variation in their climatic conditions which reflects variability in their genetic analysis. The URP primers annealed the specific sequence in the DNA of these 13 isolates they generated a profile which showed that the isolates DQBT-1, DQBT-2 have highest similarity as they are from Kerala and Meghalaya. In combined analysis of URP, ISSR and
RAPD data in which profile generated by URP and ISSR were compared with the profile generated by RAPD (Fig. 2d). Isolate DQER-1 which was collected from Uttar Pradesh is different from other and is not showing similarity with any other isolates out of the 12 isolates, this may be due to the different climatic conditions prevailing in Uttar Pradesh. However, our results on species delineation of Bipolaris spp. using molecular markers are in conformity with the findings of several workers (Kandan et al., 2014; Kandan et al., 2016; Bakonyi et al., 1995; Motlagh \& Anvari, 2010).

\section{CONCLUSION}

Morphological characterization of many pathogens of economic significance on a range of crops from different sources signifies the pivotal role of conventional diagnostic techniques. Molecular characterization using RAPD, ISSR and URP markers provided a clear resolution of relationship among all the 13 isolates belong to 6 species of Bipolaris spp. and 2 of Exserohilum and confirmed the morphological characterization of the same. Further, these molecular markers have revolutionized the genetic analysis of fungi and their application in combination with conventional techniques of detection and identification can greatly help in characterizing related genera and species of fungi.

\section{ACKNOWLEDGEMENTS}

Authors gratefully acknowledge the Director, ICARNBPGR, New Delhi and Shri Ram College of Ch. Charan Singh University, Muzaffarnagar for support and encouragement.

\section{REFERENCES}

Aggarwal, R., Sharma, V., Kharbikar, L, Lalit \& Renu. 2008. Molecular characterization of Chaetomium species using URP-PCR. Genet. Mol. Biol. 31(4): 943-946.

Akhtar, J., Kandan, A., Singh, B., Chand, D., Kumar, J. \& Agarwal, P. C. 2014. Modified technique of 
obtaining pure cultures of seed-borne fungi. Indian J Pl Protection 42(2): 156-159.

Bakonyi, J., Pomazi, A., Fischl, G. \& Hornok, L. 1995. Comparison of selected species of Bipolaris, Drechslera and Exserohilum by random amplification of polymorphic DNA. Acta Microbiol Immunol Hung 42:355-366. 1995.

Fajolu, O. L. 2012. Characterization of Bipolaris species, their effects on switchgrass biomass yield and chemical components (Ph.D. Diss.) The University of Tennessee, Knoxville, USA, PP 150.

Fatima, F., Bajpai, P., Pathak, N., Singh, S., Priya, S. \& Verma, S. R. 2015. Antimicrobial and immunomodulatory efficacy of extracellularly synthesized silver and gold nanoparticles by a novel phosphate solubilizing fungus Bipolaris tetramera. BMC Microbiol, 15:52-61. https://species.nbnatlas.org/species/BMSSYS000 004297, accessed on 20-05-2021.

Kandan A, Akhtar J, Singh B, Pal D, Chand D, Rajkumar S. \& Agarwal, P. C. 2016. Genetic diversity analysis of fungal pathogen Bipolaris sorghicola infecting Sorghum bicolor in India. J Environ Biol 37(6):1323-1330.

Kandan, A., Akhtar, J., Singh, B., Dixit, D., Chand, D., Roy, A., Rajkumar, S. \& Agarwal, P. C. 2014. Molecular diversity of Bipolaris oryzae infecting Oryza sativa in India. Phytoparasitica, 43(1):514.

Karami, S., Javan-Nikkhah, M., Bardi-Fotuhifar K., Rahjoo V., Ahmadpour, A., Alidadi, A. 2020. Study on Bipolaris and Curvularia species associated with corn, sorghum and sugarcane in Iran. Iran J Plant Prot Sci, 51(1): 129-146.

Kumar, A., Solanki, I. S., Akhtar, J. \& Gupta, V. 2016. Morpho-molecular diversity of Bipolaris oryzae causing brown spot of paddy. Indian Journal of Agricultural Sciences, 86(5): 615-620.
Kumar, P., Akhtar, J., Kandan, A., Singh, B., Kiran, R., Nair, K. \& Dubey, S. C. 2018. Efficacy of URP and ISSR markers to determine diversity of indigenous and exotic isolates of Curvularia lunata. Indian Phytopath., 71(2): 235-242.

Mathur, S. B. \& Kongsdal, O. 2003. Common laboratory seed health testing methods for detecting fungi. International Seed Testing Association, Basserdorf, Switzerland, PP. 425.

Mehta, Y. R. 2001. Molecular and pathogenic variability of Drechslera isolates from oats. Fitopatol Bras, 26(3): 590-596.

Motlagh, M. R. S. \& Anvari, M. 2010. Genetic variation in a population of Bipolaris oryzae based on RAPD-PCR in north of Iran. Afr J Biotechnol, 39(9): 5800-5804.

Motlagh, M. R. S. \& Kaviani, B. 2008. Characterization of new Bipolaris spp.: the causal agent of rice brown spot disease in the North of Iran. Int J Agric Biol, 10(6): 638-642.

Rohlf, F. J. 1988. NTSYS-pc - Numerical taxonomy and multivariate analysis system. Applied Biostatistics Inc., Port Jefferson, New York, USA (ISBN: 0-925031-31-3). PP 180.

Ueyama, A., Tsuda, M., Nishihara, N. \& Murano, S. 1975. Biology and chemistry of Helminthosporiose fungi - their historical review. Trans Mycol Soc Japn, 16: 423-434.

Valarmathi, P. \& Ladhalakshmi, D. 2018. Morphological characterization of Bipolaris oryzae causing brown spot disease of rice. Int $J$ Curr Microbiol App.Sci., 7(02): 161-170.

Weikert-Oliveira, R. C. B., Resende, M. A. D., Valério, H. M., Caligiorne, R. B. \& Paiva, E. 2002. Genetic variation among pathogens causing "Helminthosporium" diseases of rice, maize and wheat. Fitopatol Bras, 27(6): 639-643.

Citation: Singh, S., Sharma, S., Ali, A., Kandan, A., Kumar, P. and Akhtar, J. 2021. Morpho-molecular characterization of Bipolaris and Exserohilum spp. infecting various agricultural crops. International Journal of Agricultural and Applied Sciences, 2(1): 110-117. https://doi.org/10.52804/ijaas2021.21111

Copyright: (C) Singh et.al 2021. Creative Commons Attribution 4.0 International License. IJAAS allows unrestricted use, reproduction, and distribution of this article in any medium by providing adequate credit to the author(s) and the source of publication. 